\title{
Pembelajaran dengan Teknik Pelatihan Untuk Meningkatkan Kemampuan Menulis Surat Pribadi pada Siswa Kelas VII C SMP Negeri 9 Kota Jambi Tahun Pelajaran 2014/2015
}

\author{
Sri Sambodi ${ }^{1}$
}

\begin{abstract}
Abstrak. Rendahnya minat siswa dalam menulis surat harus ditanggapi oleh para guru, upaya meningkatkan gairah menulis siswa, guru berupaya meningkatkan teknik dan kemampuan siswa melalui penulisan surat. Tujuan dalam penelitian ini diantaranya pertama untuk mendiskripsikan tingkat kemampuan siswa dalam menulis surat pribadi melalui teknik pelatihan siswa, kedua Memperbaiki proses pembelajaran menulis surat pribadi pada siswa, dan ketiga Meningkatkan kemampuan menulis surat pribadi melalui teknik pelatihan agar siswa mencapai nilai di atas KKM. Dalam penelitian ini rancangan penelitian yang digunakan adalah penelitian tindakan kelas (PTK) dengan dilakukan tindakan melalui siklus I dan siklus II. Rruang lingkup penelitian ini adalah pembelajaran di dalam kelas yang dilaksanakan oleh guru dan siswa untuk melakukan perbaikan yang berdampak pada peningkatan hasil belajar peserta didik. Hasil dari penelitian ini terlihat bahwa pada siklus I nilai kemampuan menulis surat pribadi pada siklus pertama sebesar 66,00 dengan kategori cukup. Sedangkan kemampuan menulis surat pribadi pada siklus dua diperoleh nilai rata-rata 77,83 dengan kategori baik mengalami peningkatan 11,33 atau 17,20\%.
\end{abstract}

Kata kunci: Teknik, Kemamupan, Siswa.

Abstract: The low interest of students in writing letters must be responded to by the teachers, efforts to increase the passion of writing students, teachers try to improve the techniques and abilities of students through letter writing. The objectives of this study include the first to describe the level of students' ability to write personal letters through student training techniques, second Improve the learning process of writing personal letters to students, and third Improve the ability to write personal letters through training techniques so students achieve grades above KKM. In this study, the research design used was classroom action research (CAR) by taking action through cycle I and cycle II. The scope of this research is classroom learning carried out by teachers and students to make improvements that have an impact on improving student learning outcomes. The results of this study show that in the first cycle the value of the ability to write a personal letter in the first cycle was 66.00 with sufficient categories. While the ability to write a personal letter in the second cycle obtained an average value of 77.83 with a good category experiencing an increase of 11.33 or $17.20 \%$.

Keywords: Engineering, Ability, Students.

\section{PENDAHULUAN}

Bahasa sangat penting bagi manusia untuk berkomunikasi dengan orang lain. Dalam komunikasi tersebut terjadi tukar menukar informasi dan pengalaman. Informasi tersebut dapat berupa ide, gagasan, pendapat, ataupun yang lain. Agar informasi yang disampaikan dapat dengan mudah dimengerti dan dipahami, maka sarana yang diperlukan adalah bahasa. Bahasa merupakan alat untuk menyampaikan pikiran dan keinginan kepada orang lain.

Berkomunikasi dengan menggunakan bahasa antara komunikan dengan komunikator perlu adanya pengetahuan bahasa yang memadai. Sering terjadi kesulitan antara komunikan dengan komunikator dalam menyampaikan pikiran, perasaan, dan keinginannya karena antara mereka kurang pengetahuan tentang bahasa. Ini berarti bahasa seseorang dapat mencerminkan pikirannya. "Bahasa seseorang mencerminkan pikirannya. Semakin terampil seseorang berbahasa, semakin cerah dan jelas pula jalan pikirannya" (Tarigan, 2008:1).

Dalam pendidikan formal, pembelajaran bahasa terdapat empat aspek keterampilan berbahasa, yaitu (a) mendengar, (b) berbicara, (c) membaca, dan (d) menulis. Keempat aspek keterampilan berbahasa tersebut merupakan tujuan akhir pengajaran bahasa yang harus dimiliki dan dikuasai oleh semua siswa. Jika dilihat dari urutan pemerolehan keterampilan bebrbahasa tersebut, menulis merupakan urutan yang keempat. Hal ini menunjukkan bahwa menulis bukanlah sesuatu yang mudah karena untuk dapat menghasilkan tulisan

${ }^{1}$ SMP Negeri 9 Kota Jambi 
yang baik siswa dituntut memiliki kemampuan-kemampuan yang lain. Kemampuan tersebut mencakup pengetahuan tentang hal yang akan ditulis dan bagaimana menuangkan ide, pikiran, dan gagasan yang dimiliki ke dalam tulisan.

Pembelajaran Bahasa Indonesia di kelas VII C semester ganjil dengan standar kompetensi menulis. 1. Mengungkapkan pikiran dan pengalaman dalam buku harian dan surat pribadi. 1.1. Menulis surat pribadi dengan memperhatikan komposisi isi dan bahasa. Kegiatan menulis bukan panjang tulisan yang dipentingkan, melainkan kejelasan isi tulisan serta efisiensi pemakaian dan pemilihan kata. Karena itu, selama kegiatan menulis berlangsung siswa perlu disadarkan bahwa ada cara penataan atau penyusunan kata dalam pembelajaran keterampilan menulis (Purwo, 1997:7).

Berdasarkan pengamatan terhadap proses pembelajaran bahasa Indonesia di SMP Negeri 9 Kota Jambi kelas VII C semester ganjil 2014/2015, pembelajaran kemampuan menulis surat pribadi siswa belum mencapai KKM yang ditetapkan di SMP Negeri 9 Kota Jambi yaitu 75,00. Dalam kegiatan pembelajaran menulis surat pribadi dari jumlah siswa 30 siswa kelas VII C, siswa yang mencapai KKM hanya 10 orang $(33,3 \%)$, siswa yang belum mencapai KKM20 orang $(66,6 \%)$. Hal ini dibuktikan oleh hasil tes unjuk kerja ketika disuruh menulis surat pribadi masih tergolong rendah. Dari 30 siswa hanya 1 yg memiliki kemampuan baik sekali dengan persentase 3,33\% , 6 siswa memiliki kemampuan baik dengan persentase $20 \%$, 9 siswa memiliki kemampuan cukup, 9 siswa dengan persentase 30\%, 14 siswa memiliki kemampuan kurang dengan persentase 46,66\%. Hasil rata -rata uji blok kategori kurang . Untuk mengatasi hal-hal di atas, idealnya guru harus mempunyai kreativitas dalam pembelajaran, khususnya pada materi keterampilan menulis, terutama metode atau teknik yang digunakan. Dalam hal ini, guru benarbenar dituntut kreativitasnya dan dapat mencari solusi yang tepat. Guru harus mampu memvariasikan pembelajaran bahasa Indonesia agar menarik dan menyenangkan. Apabila guru dapat menggunakan teknik atau metode yang tepat, maka proses pembelajaran di kelas tidak lagi membosankan. Selain dari faktor siswa, masalah yang menyebabkan pembelajaran menulis surat pribadi pada siswa kelas VII C SMP Negeri 9 Kota Jambi adalah faktor guru, diantaranya

a. Guru kurang tanggap dalam menentukan teknik yang digunakan sehingga proses belajar mengajar terkesan monoton dan membosankan.

b. Guru belum mengaitkan materi pembelajaran dengan pengalaman siswa, sehingga terkesan proses pembelajaran masih terpusat pada guru.

c. Sistem evaluasi tidak berorientasi pada proses, tetapi lebih ditekankan pada hasil akhir.

Untuk mengatasi permasalahan di atas, diperlukan upaya nyata dalam proses pembelajaran, misalnya dengan menggunakan teknik pelatihan. Teknik pelatihan merupakan salah satu teknik pembelajaran yang dapat digunakan, karena memenuhi beberapa kelebihan. Teknik pelatihan mempunyai kelebihan antara lain (1) anak didik akan dapat menggunakan daya pikirnya yang makin lama makin bertambah baik, karena dengan pengajaran yang baik maka anak didik akan menjadi lebih teratur dan lebih teliti dalam mendorong daya ingatnya dan (2) pengetahuan anak didik yang bertambah tersebut akan memperoleh pemahaman yang lebih baik dan mendalam. Kegiatan menulis merupakan suatu kegiatan yang kompleks karena di dalamnya terdapat unsur-unsur keterampilan bahasa yang lain.

Untuk itu, siswa akan mampu menulis apabila ia menguasai aspek berbahasa yang lain seperti membaca, mendengar, dan berbicara. Jadi empat aspek keterampilan berbahasa tersebut sangat berhubungan satu dengan yang lain. Untuk keterampilan menulis siswa harus sering berlatih, jadi dalam pelaksanaan pembelajaran Bahasa Indonesia khususnya pada pembelajaran menulis guru harus lebih terampil untuk menyiasati agar siswa tertarik untuk mengerjakan latihan- latihan menulis, misalnya menulis surat pribadi, karena dengan banyak berlatih siswa akan terbiasa dan akan memiliki ketangkasan atau keterampilan yang lebih tinggi dari apa yang telah dipelajari. Berdasarkan uraian di atas penulis merasa perlu memperbaiki proses pembelajaran dengan teknik pelatihan untuk meningkatkan kemampuan menulis surat pribadi pada siswa kelas VII C SMP Negeri 9 Kota Jambi tahun pelajaran 2014/2015. Ada beberapa tujuan dalam penelitian ini diantaranya pertama untuk mendiskripsikan tingkat kemampuan siswa dalam menulis surat pribadi melalui teknik pelatihan siswa, kedua Memperbaiki proses pembelajaran menulis surat pribadi pada siswa, dan ketiga Meningkatkan kemampuan menulis surat pribadi melalui teknik pelatihan agar siswa mencapai nilai di atas KKM. 


\section{Landasan Teori \\ Konsep Dasar Menulis}

Menulis merupakan salah satu dari empat keterampilan berbahasa yang harus dikuasai oleh setiap orang. Menulis dapat didefinisikan sebagi suatu kegiatan penyampaian pesan dengan menggunakan bahasa tulis sebagai alat atau media. Menulis adalah suatu proses kegiatan menuangkan pikiran manusia yang hendak mengungkapkan kandungan jiwanya kepada orang lain atau kepada dirinya sendiri dalam bentuk tulisan (Widyamartaya, 1991:9). Menulis adalah menuangkan gagasan, pikiran, perasaan dan pengalaman melalui bahasa tulis (Depdiknas, 2003:6).

Berdasarkan beberapa teori peneliti menyimpulkan bahwa menulis adalah menuangkan gagasan, pikiran, perasaan, dan pengalaman bentuk tulisan sehingga menjadi sebuah hasil karangan di mana pembaca seolah-olah merasakan atau mengalami sendiri apa yang ia baca.

Dalam pembelajaran Bahasa Indonesia aspek keterampilan menulis sangat beragam, seperti menulis sastra, yang di dalamnya terdapat menulis mengenai prosa, puisi, dan drama, menulis kreatif seperti mengarang, yang di dalamnya terdapat lima jenis tulisan yaitu narasi, deskripsi, eksposisi, persuasi, dan argumentasi, dan masih banyak jenis-jenis tulisan lain. Pada penelitian tindakan kelas, penulis akan mengangkat permasalahan mengenai menulis surat pribadi. Setiap siswa pasti memiliki pengalaman, baik yang menyenangkan ataupun menyedihkan. Tidak setiap siswa mampu menuangkannya dalam sebuah tulisan, walau sebenarnya apa yang mereka tulis merupakan benar-benar pengalaman/kejadian yang mereka alami sendiri.

Menulis menurunkan atau melukiskan lambang-lambang grafik yang menggambarkan suatu bahasa yang dipahami seseorang, sehingga orang lain dapat membaca grafik tersebut kalau mereka memahami bahasa dan gambaran grafik itu." (Tarigan, 2008: 21). Pendapat lain mengatakan "Menulis berarti mengorganisasikan gagasan secara sistematis serta mengungkapkan secara tersurat." (Sabarti, 2003: 2).

Berdasarkan pendapat di atas, dapat disimpulkan bahwa menulis adalah suatu proses kegiatan mengungkapkan pikiran, perasaan, sikap dan keyakinan dengan menggunakan lambang-lambang bahasa tertulis secara logis dan sistematis. Tulisan yang baik hendaknya mengandung isi yang berbobot, jelas, singkat, menarik, dan mudah dipahami. Apabila seseorang berhasrat menyampaikan pikiran, sikap, perasaan, dan keyakinan serta mantap dan mampu menyampaikan dalam bahasa tulis, maka ia telah memiliki keterampilan dan kemampuan menulis.

Tujuan menulis adalah memproyeksikan sesuatu mengenai diri seseorang. Menulis tidak mengharuskan memilih suatu pokok pembicaraan yang cocok dan sesuai, tetapi harus menentukan siapa yang akan membaca tulisan tersebut dan apa maksud dan tujuannya. Dalam Kurikulum Tingkat Satuan Pendidikan (KTSP) diungkapkan bahwa tujuan pembelajaran menulis standar kompetensi bahasa dan sastra Indonesia Sekolah Menengah Pertama (SMP) adalah siswa mampu mengekspresikan berbagai pikiran, gagasan, pendapat, dan perasaan dalam berbagai ragam tulisan. Artinya, siswa terampil menulis secara efektif dan efisien berbagai ragam tulisan dalam berbagai konteks. Berdasarkan uraian mengenai tujuan menulis yang disampaikan di atas, dapat diketahui bahwa menulis mengandung tujuan untuk melatih diri siswa memiliki kompetensi menulis dalam menyampaikan pendapat dan perasaannya.

\section{Pengertian Surat}

Menurut Irman (2008 : 138), surat adalah salah satu sarana komunikasi tertulis untuk menyampaikan informasi dari satu pihak (orang, instansi, atau organisasi) kepada pihak lain (orang, instansi, atau organisasi). Menurut Simorangkir (2004 : 1), surat adalah alat komunikasi penyampaian informasi secara tertulis dari satu pihak ke pihak lain. Berdasarkan dua pendapat di atas, surat dapat diartikan sebagai alat/media komunikasi tertulis untuk menyampaikan berita dari satu pihak kepada pihak lain.Surat juga memilki fungsi dan jenisnya.

Menurut Slamet (1996 : 18), fungsi surat adalah sebagai: 1) alat penghubung secara tertulis, 2) bukti hitam di atas putih yang mempunyai kekuatan hokum, 3) alat pengingat, 4) bukti sejarah (historis) untuk bahan riset, 5) bahan dokumentasi, 6) duta atau wakil seseorang atau instansi, 7) keamanan dalam melakukan aktivitas, 8) barometer maju mundurnya suatu kantor, dan 9) media dalam berkomunikasi. Sedangkan jenis surat dapat dikelompokkanberdasarkan hal-hal berikut:

a. Berdasarkan Situasi 
Berdasarkan situasinya, surat dapat dibedakan menjadi 2 jenis yaitu:

1. Surat resmi

2. Surat tidak resmi

b. Berdasarkan Pembuat Surat

Berdasarkan pembuat atau penulisannya, surat dapat dibedakan menjadi 2 jenis, yaitu:

1. Surat pribadi

2. Surat resmi

\section{Surat Pribadi}

Surat pribadi merupakan surat yang dibuat oleh seseorang atas nama pribadi dan ditujukan kepada orang lain seperti saudara, atau teman dengan tujuan tertentu (Lestari, 2005: 63). Menurut Slamet (1999: 81) surat pribadi ialah surat yang dibuat seseorang yang isinya menyangkur kepentingan pribadi. Senada dengaan pendapat di atas, surat pribadi adalah surat yang ditulis dan dikirim atas nama pribadi (Nurviati, 1995:30). Bagian-bagian surat pribadi yang lengkap adalah

1. Alamat Surat. Alamat surat berfungsi untuk:

a. Alamat penunjuk langsung bagi si penerima

b. Petunjuk bagi petugas kearsipan sehubungan dengan sistem penyimpanan Contoh penulisan alamat surat

Kepada Yth. Sahabatku Rina

Jln. Taman Sari No. 79

Bandung.

2. Tanggal Pembuatan Surat

Pengetikan atau penulisan tanggal, bulan, dan tahun harus lengkap dan di belakang tahun tidak diberi tanda titik. Tanggal surat berfungsi untuk mengetahui surat itu dibuat oleh si pengirim surat

3. Salam Pembuka. Salam pembuka berfungsi untuk menyapa atau member salam apabila ia bertemu atau ingin berbicara dengan orang lain, dan orang tersebut belum dikenalnya.

4. Bagian Isi. Isi surat adalah hal atau masalah pokok dari surat. Pokok pikiran yang dituangkan ke dalam surat merupakan maksud dan tujuan pokok penulisan surat kepada seseorang. Isi surat dapat terdiri atas beberapa paragraf. Hal ini tergantung pada banyaknya pembiacaraaan yang disampaikan sesuai dengan kebutuhan. Isi surat usahakan jelas, mudah dipahami, susunan bahasa baik, sopan, dan tidak bertele-tele.

5. Bagian Penutup. Bagian penutup berfungsi sebagai penutup atau penegasan surat.

6. Salam Penutup Salam penutup berfungsi untuk menunjukkan rasa hormat dan keakraban pengirim surat terhadap penerima surat.

7. Nama Pengirim Nama pengirim adalah nama terang si pengirim surat brfungsi sebagai tanda pengesahan surat yang dibuat atau dikirimkan kepada pihak lain.

Surat pribadi memiliki ciri-ciri dan juga isi surat pribadi. Adapun ciri-ciri dari surat pribadi diantaranya: 1) bagian surat tidak selengkap surat dinas, 2) bahasa yang digunakan bersifat subyektif, 3) cara penulisan tidak ada peraturan yang mengikat, 4) bebas menggunakan perlengkapan surat, sesuai dengan pilihannya baik penggunaan kertas ataupun sampul surat. Sedangkan isi surat pribadi mencakup: 1) bersifat kekeluargaan, 2) ditujukan kepada orang yang lebih tua, 3) bersifat setengah resmi misalnya surat izin tidak masuk sekolah, surat izin cuti

\section{Kemampuan Menulis Surat Pribadi}

Kemampuan adalah kesanggupan; kekuatan; dan kecakapan untuk melakukan sesuatu (Depdiknas, 2003: 20). Seseorang dikatakan memiliki pengetahuan apabila ia sanggup dan cakap menerapkan pengetahuan yang dimilikinya. Menulis adalah "Menurunkan atau melukiskan lambang-lambang grafik yang menggambarkan suatu bahasa yang dipahami oleh sesorang, sehingga orang lain dapat membaca lambang-lambang grafik tersebut kalau mereka memahami bahasa grafik tersebut" (Tarigan, 1982: 21).

Dari beberapa pengertian di atas, maka dapat disimpulkan bahwa kemampuan menulis surat pribadi adalah kemampuan menurunkan ide-ide dalam bentuk surat dengan lambang-lambang grafik yang menggambarkan suatu bahasa agar dapat dibaca dan dimengerti oleh penerima atau pembaca surat. 


\section{Pembelajaran Menulis}

Pembelajaran menulis merupakan suatu kegiatan yang berencana dan bertujuan. Pembelajaran menulis terdapat dalam pembelajaran keterampilan bahasa disamping keterampilan menyimak, berbicara, dan keterampilan membaca. Keempat keterampilan berbahasa tersebut dalam pembelajaran harus mendapat porsi yang seimbang dan pelakasanaannya dilakukan secara terpadu serta intensif. Tujuan menulis adalah membantu siswa untuk mengembangkan kemampuan berkomunikasi secara tertulis. Hal terpenting dalam kegiatan menulis bukan panjang tulisan yang dihasilkan siswa, melainkan kejelasan isi tulisan, efisiensi pemakaian, dan pemilihan kata diksi. Selama kegiatan menulis berlangsung siswa perlu disadarkan bahwa ada berbagai kemungkinan cara untuk penataan atau pemilihan kata. Menurut Semi (1989: 100), tujuan pembelajaran menulis adalah

1. Siswa mampu menyusun buah pikiran, perasaan, dan pengalaman ke dalam susunan atau komposisi yang baik.

2. Merangsang imajinasi atau daya pikir intelek siswa.

3. Siswa mampu menggunakan perangkat kaidah menulis dan menggunakan kebahasaan sewaktu menulis.

4. Siswa mampu menyusun berbagai bentuk karangan (surat, laporan, artikel, dan lain-lain).

5. Mengembangkan kebiasaan menulis yang akurat, singkat, dan jelas, serta menarik.

\section{Teknik Pelatihan}

Teknik berarti cara atau jalan yang ditempuh. Teknik mengajar adalah cara yang digunakan guru dalam mengadakan hubungan dengan siswa pada saat berlangsungnya pelajaran (Suryo Broto, 1966: 36). Teknik diartikan sebagai metode atau sistem mengerjakan sesuatu (KBBI, 2001: 1158). Dalam Pembelajaran Bahasa Indonesia, teknik ini mengacu pada implementasi perencanaan pembelajaran bahasa Indonesia di depan kelas. Teknik bersifat prosedural. Teknik yang baik dijabarkan dengan metode yang serasi dengan pendekatan.

Roestiyah N.K (2008: 125). Teknik latihan bertujuan untuk meningkatkan kemampuan siswa, untuk itu dalam proses pelaksanaan pembelajaran siswa harus diberi kesempatan untuk melatih kemampuannya tersebut, dan guru berperan sebagai komentator, kritikus atau pembimbing atau dia boleh juga memberikan aktivitas yang cocok seperti "games" yang memungkinkan siswa belajar berdiskusi sesama mereka. Jadi, jika kita membicarakan aktivitas siswa dalam pendidikan yang kita maksudkan adalah siswa aktif secara mental, dan sensitif secara emosional, melatih kemampuan dan pengalamannya dengan melaksanakannya.

Penggunaan istilah latihan sering disamakan artinya dengan istilah ulangan. Padahal maksudnya berbeda. Latihan bermaksud agar pengetahuan dan kecakapan tertentu dapat menjadi milik siswa atau peserta didik dan dikuasai sepenuhnya, sedangkan ulangan hanya sekedar mengukur sebagaimana dia telah menyerak pengajaran tersebut (Darajat, 2004: 302). Dalam teknik pelatihan terdapat langkah-langkah sebagai berikut:

1. Guru mengemukakan materi yang akan di pelajari dan memberikan pengarahan mengenai cara - cara pelaksanaan tugas pada materi tersebut. Artinya, pokok permasalahan yang akan dikerjakan siswa dibahas oleh guru dan siswa. Dalam hal ini guru harus merumuskan permasalahan yang akan dikerjakan dengan sejelas jelasnya agar dapat dipahami oleh siswa

2. Aabila dipandang siswa telah siap mengerjakan tugas, maka guru membagikan lembar kerja kepada siswa.

3. Guru memberikan bimbingan kepada siswa secara satu persatu. Dengan pada waktu proses pelaksanaan penugasan, guru mendatangi siswa cara untuk iberikan bimbingan atau arahan

4. pada pelaksanaan pelatihan, harus berjalan dalam suasana bebas, setiap siswa diberikan arahan untuk dijadikan acuan dalam penulisan.

Dalam setiap proses pembelajaran guru harus pandai memilih suatu teknik, metodem atau pendekatan tertentu yang dipandang sesuai dengan materi pembelajaran yang akan disampaikan. Setiap teknik yang dipilih pasti memiliki keunggulan dan kelemahan, teknik apapun itu, tidak terkecuali pada teknik pelatihan. Berikut beberapa keunggulan teknik pelatihan menurut Zakiah Darajat (2004: 302).: 
1. Anak didik akan dapat menggunakan daya pikirnya yang makin lama makin bertambah baik, karena dengan pengajaran yang baik maka anank didika akan menjadi lebih teratur dan lebih teliti dalam mendorong daya ingatannya. Ini berarti daya berpikirnya bertambah.

2. Pengetahuan anak didik bertambah dari berbagai segi, dan anak didik tersebut akan memperoleh pemahaman yang lebih baik dan lebih mendalam.

Telah dibahas di atas tentang keunggulan dari teknik pelatihan yang harus diperhatikan oleh seorang guru.Untuk itu, guru harus memperhatikan beberapa hal yang merupakan kelemahan dari teknik pelatihan, di antaranya;

1. Dalam latihan sering terjadi cara-cara/gerak yang tidak bisa berubah, karena merupakan cara yang telah dibakukan. Hal ini akan menghambat bakat dan inisiatif siswa.

2. Terkadang latihan itu langsung dijalankan tanpa penjelasan sebelumnya, sehingga siswa tidak paham.

3. Walau tidak mengerti maksud dan tujuan dari latihan, namun siswa tetap melaksanakan latihan tersebut.

4. Suatu latihan yang dijalankan dengan cara tertentu yang telah dianggap baik dan tepat, sehingga tidak boleh diubah, mengakibatkan keterampilan yang diperoleh siswa umumnya juga menetap/pasti, yang akan merupakan kebiasaan yang kaku atau keterampilan yang salah.

Untuk mengatasi kelemahan-kelemahan dalam teknik pelatihan ini dapat dilakukan dengan bermacammacam, antara lain: 1) latihan hanya untuk bahan atau tindakan yang bersifat otomatis, 2) latihan harus memiliki arti yang luas, karenanya: (a) menjelaskan terlebih dahulu tujuan latihan tersebut, (b) agar siswa dapat memahami manfaat latihan itu buat kehidupan siswa, dan (c) siswa perlu mempunyai sikap bahwa latihan ini diperlukan untuk melengkapi belajar. 3) masa latihan relatif singkat, tetapi harus sering dilakukan pada waktu- waktu tertentu. 4) latihan harus menarik, gembira, dan tidak membosankan. Untuk itu perlu: (a) tiap-tiap kemajuan yang akan dicapai harus jelas, (b) hasil latihan terbaik dengan sedikit menggunakan emosi. 5) proses latihan dan kebutuhan-kebutuhan harus disesuaikan dengan proses perbedaan individual: (a) tingkat kecakapan yang diterima pada satu titik perlu sama, (b) perlu diberikan perorangan dalam rangka menambah latihan kelompok.

\section{METODE PENELITIAN}

Dalam penelitian ini rancangan penelitian yang digunakan adalah penelitian tindakan kelas (PTK), ruang lingkup penelitian ini adalah pembelajaran di dalam kelas yang dilaksanakan oleh guru dan siswa untuk melakukan perbaikan yang berdampak pada peningkatan hasil belajar peserta didik (Kusuma, 2009: 141). Pada konsep PTK terdiri atas empat tahap, yaitu perencanaan, tindakan, observasi, dan refleksi. Hubungan keempat tahap tersebut dikenal sebagai siklus. Untuk lebih jelasnya, dalam penelitian ini menggunakan 2 suklis kegiatan dengan rancangan PTK model Kusuma adalah sebagai berikut:

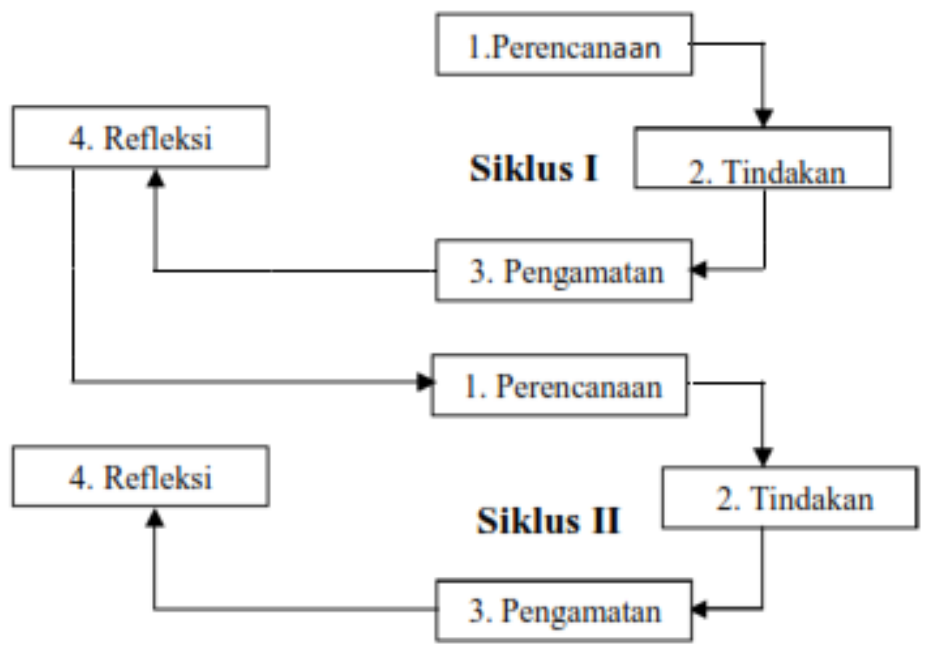

Gambar 1 Siklus Penelitian

Pelaksanaan tindakan siklus disesuaikan dengan kebutuhan dalam upaya peningkatan hasil pembelajaran. Jika terdapat peningkatan dalam pembelajaran yang sesuai dengan indikator, maka siklus 
tersebut dapat dihentikan, meskipun masih dalam siklus kedua. Siklus juga dapat dihentikan apabila dirasa tidak ada perubahan hasil belajar dalam setiap tahapan yang telah dilalui karena akan menimbulkan kejenuhan pada siswa. Penelitian dilaksanakan di SMP Negeri 9 Kota Jambi Kecamatan Jambi Timur, Kota Jambi. Penelitian dilaksanakan pada semester ganjil tahun pelajaran 2014/2015 terhitung dari bulan September sampai dengan Nopember 2014 (3 bulan). Penelitian tindakan kelas dilaksanakan sesuai dengan jadwal pelajaran. Subjek penelitian tindakan ini dilaksanakan pada kelas VII C Sekolah Menengah Pertama Negeri 9 Kota Jambi tahun pelajaran 2014/2015 dengan jumlah siswa 38 siswa, yang terdiri atas 23 siswa laki-laki dan 15 siswa perempuan.

Prosedur penelitian yang digunakan oleh peneliti adalan menggunakan daur ulang atau siklus. Tiap siklus terdiri atas empat kegiatan inti, yaitu: perencanaan, tindakan, obsevasi, dan refleksi. Kegiatan pertama penelitian didahulukan dengan menemukan masalah dan berupaya mencari solusi berupa perencanaan perbaikan (perenungan). Lalu dilanjutkan dengan tindakan yang telah direncanakan sehingga menghasilkan perbaikan untuk tindakan selanjutnya pada siklus-siklus berikutnya.

\section{HASIL DAN PEMBAHASAN}

Pelaksanaan penelitian dilaksanakan di SMP Negeri 9 Kota Jambi, peneliti dibantu oleh seorang kolaborator, yaitu teman sejawat yang memberikan masukan dalam rangka pengumpulan data selama pelajaran berlangsung, baik segi kelebihan maupun kekurangan yang terjadi selama proses pembelajaran menulis surat pribadi dengan menggunakan teknik pelatihan. Setiap siklus dalam penelitian ini dilaksanakan dalam dua kali tatap muka atau 4x40 menit. Setiap tindakan dalam setiap siklus merupakan tahapan yang berkesinambungan.

Dalam menulis surat pribadi siswa terlebih dahulu mencermati dan memahami contoh surat pribadi kemudian siswa mengerjakan soal yang diberikan oleh guru. Hasil yang dikumpulkan adalah pekerjaan siswa yang sesuai dengan kompetensi dasar menulis surat pribadi siswa kelas VII C semester ganjil. Setiap siklus dalam penelitian ini terdiri dari perencanaan, pelaksanan tindakan, pengamatan, dan refleksi. Refleksi dilakukan untuk memperbaiki pelaksanaan tindakan pada siklus berikutnya. Proses pembelajaran menulis dengan menerapkan teknik pelatihan meliputi aktivitas guru dan siswa dalam proses keterampilan menulis. Aktivitas guru terkait dengan persiapan pembelajaran, mengarahkan keterkaitan pembelajaran menulis surat pribadi, memantau aktivitas siswa di dalam penelitian ini adalah aktivitas yang berkaitan dengan penerapan teknik pelatihan yang dinilai dalam penulisan surat pribadi yaitu kelengkapan unsur-unsur surat, struktur kalimat, kesesuaian isi surat, diksi, dan ejaan.

\section{Siklus I}

Pelaksanaan pembelajaran siklus adalah menulis surat pribadi yang dilaksanakan dalam dua kali tatap muka. Setiap tatap muka merupakan tahapan pembelajaran yang berkesinambungan. Berdasarkan pengamatan yang dilakukan oleh observer terhadap aktivitas siswa dalam proses pembelajaran bahasa Indonesia dalam menulis surat pribadi pada prasiklus masih di bawah standar. Pelaksanaan penilaian menulis surat pribadi dilakukan untuk menentukan tingkat ketuntasan belajar pada pembelajaran siklus satu hal ini dapat dilihat pada grafik berikut:

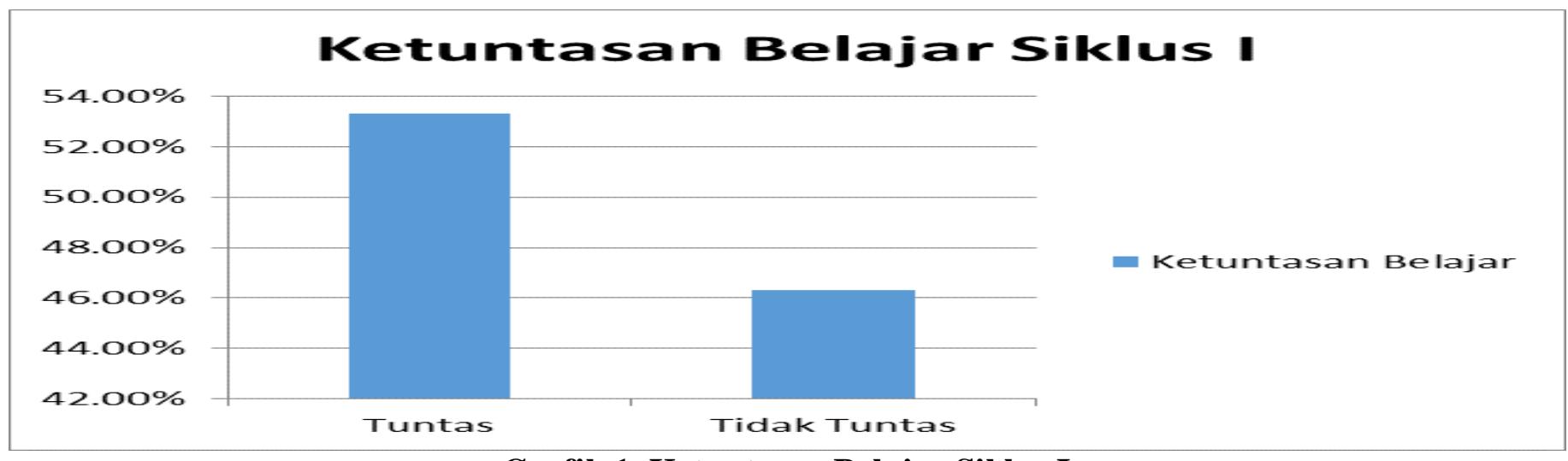

Grafik 1. Ketuntasan Belajar Siklus I 
Grafik 1 menunjukkan dari 30 siswa hanya 16 siswa atau 53,33\% yang sudah tuntas belajar dengan KKM 70,00. Dengan demikian, masih ada 14 siswa atau 46,33\% yang belum mencapai KKM. Untuk mengetahui penyebab gagalnya 14 siswa guru peneliti dan guru kolaborator mendiskusikan hal-hal yang menyebabkan 14 siswa belum tuntas pada kegiatan refleksi. Nilai rerata kelas pembelajaran siklus I adalah $67,5 \%$, dan nilai ini belum mencapai KKM yaitu 70,00. Nilai tertinggi adalah 90 dan nilai terendah adalah 55. Berasarkan gambar pengamatan yang ditulis teman sejawat sebagai kolaborator, proses pembelajaran dalam siklus I belum mencapai indikator yang diharapkan dalam penetitian ini. Hal ini dapat dilihat pada tabel 1 berikut:

Tabel 1

Tingkat Kemampuan Menulis Surat Pribadi siklus I dengan Menggunakan Pelatihan Tugas Kelompok

\begin{tabular}{|c|c|c|c|}
\hline No & Aspek Penilaian & Skor Rata-Rata & Kategori \\
\hline 1 & Kelengkapan unsur-unsur surat & 75,00 & Baik \\
\hline 2 & Struktur kalimat & 67,50 & Cukup \\
\hline 3 & Kesesuaian isi surat & 75,00 & Baik \\
\hline 4 & Diksi & 73,00 & Cukup \\
\hline 5 & Ejaan & 39,16 & Sangat Kurang \\
\hline & Skor rata-rata & 66,00 & Cukup \\
\hline
\end{tabular}

Berdasarkan tabel di atas, dapat dikemukakan hal-hal sebagai berikut. Skor rata-rata siswa dalam menentukan kelengkapan unsur-unsur surat 75,00 (tergolong kategori cukup), skor rata-rata siswa dalam menulis struktur kalimat adalah 67,50\% (tergolong kategori cukup), skor kesesuaian isi surat 75,00 (tergolong kategori baik), skor diksi 73,00 (kategori cukup), skor ejaan adalah 39,16 (kategori sangat kurang). Hal ini menunjukkan bahwa tingkat kemampuan siswa dalam menulis surat pribadi belum mencapai indikator (KKM) yaitu 70,00.

Setelah pelaksanaan tindakan, peneliti dan kolaborator membahas kelemahan atau kendala-kendala yang muncul selama penelitian berlangsung, kemudian mencari solusi sebagai bentuk perbaikan yang diterapkan pada siklus berikutnya. Dengan kata lain hasil refleksi digunakan sebagai dasar tindak lanjut sebagai upaya perbaikan untuk mencapai tujuan penelitian. Dari tindakan siklus I ada yang berhasil dan ada yang belum berhasil. Berikut hasil refleksi dapat dilihat dari hasil pengamatan aktivitas Siswa dalam proses pembelajaran menulis surat pribadi melalui teknik pelatihan pada siklus 1 yang dapat dilihat pada tabel di bawah ini:

Tabel 2

Hasil Pengamatan Aktivitas Siswa dalam Proses Pembelajaran Menulis Surat Pribadi Harian Melalui Teknik Pelatihan pada Siklus I

\begin{tabular}{|c|c|c|c|c|c|}
\hline \multirow[t]{2}{*}{ No } & \multirow[t]{2}{*}{ Aktivitas siswa } & P1 & $\mathbf{P 2}$ & \multirow{2}{*}{$\begin{array}{l}\text { Rata } \\
\text {-rata }\end{array}$} & \multirow{2}{*}{$\begin{array}{l}\text { Persentase } \\
(\%)\end{array}$} \\
\hline & & \multicolumn{2}{|c|}{ Skor } & & \\
\hline 1. & Siswa berinteraksi bersama teman-temanya selama pembelajaran. & 3 & 3 & 3 & 60 \\
\hline 2. & Siswa memberikan respon terhadap materi pembelajaran. & 4 & 3 & 3,5 & 70 \\
\hline 3. & Siswa mengajukan pertanyaan. & 4 & 4 & 4 & 80 \\
\hline 4. & Siswa menjawab pertanyaan. & 4 & 3 & 3,5 & 70 \\
\hline 5. & Siswa berperan aktif dalam pembelajaran. & 3 & 3 & 3 & 60 \\
\hline 6. & Siswa mengerjakan tugas tidak tepat waktu. & 4 & 2 & 3 & 60 \\
\hline 7. & Siswa mengungkapkan ide dalam pembelajaran. & 3 & 3 & 3 & 60 \\
\hline 8. & $\begin{array}{l}\text { Siswa mendiskusikan idenya dengan teman dan mewujudkan dalam bentuk } \\
\text { pembelajaran. }\end{array}$ & 3 & 5 & 4 & 80 \\
\hline 9. & Siswa mengganggu temannya. & 3 & 3 & 3 & 60 \\
\hline 10. & Siswa keluar masuk kelas dalam jam pelajaran. & 3 & 3 & 3 & 60 \\
\hline & Jumlah Skor & 36 & 36 & 36 & \\
\hline & Rata-rata keseluruhan $36 \times 100 \%=72,00$ & & & & \\
\hline
\end{tabular}

Kategori :

1. $>75,00$

2. $65,00-75$

$=$ Sangat Aktif

$=$ Aktif 
$\begin{array}{ll}\text { 3. } 55,00_{-} 65,00 & =\text { Cukup } \\ \text { 4. } 40,00_{-} 55,00 & =\text { Kuran Aktif } \\ \text { 5. }<40,00 & =\text { Tidak Aktif }\end{array}$

Berdasarkan pengamatan yang dilakukan oleh observer terhadap aktivitas siswa dalam proses pembelajaran bahasa Indonesia dalam menulis surat pribadi pada siklus 1 yaitu 72,00, hasil ini masih dibawah $75 \%$ dan tergolong kategori cukup.

Penelitian pada siklus satu merencanakan menggunakan teknik pelatihan secara individu. Hal ini dilakukan karena penggunaan metode pelatihan secara kelompok hasilnya kurang maksimal dan masih perlu diperbaiki. Diharapkan dengan metode pelatihan secara individu dapat melatih siswa untuk bekerja secara serius dan bertanggung jawab dengan tugas yang diberikan oleh guru. Agar siklus berikutnya dengan menerapkan teknik pelatihan secara individu dapt meningkat, maka perlu dibuat rekomendasinya. Rekomendasi yang harus dilakukan untuk perbaikan pada siklus satu adalah (1) RPP dibuat lebih rinci untuk memperjelas kegiatan dengan metode pelatihan. (2) Guru harus lebih jelas dalam menyampaikan materi pelajaran sehingga mudah dipahami. (3) Guru harus lebih sabar dalam membimb ing dan mengarahkan siswa, serta memberikan motivasi agar siswa lebih aktif dalam proses pembelajaran. (4) Guru mencoba mengubah metode palatihan secara kelompok menjadi tugas individu agar siswa lebih bertanggung jawab dan dapat memperoleh hasil sesuai yang diharapkan.

\section{Siklus II}

Pelaksanaan siklus dua merupakan tindak lanjut dan refleksi dari pelaksanaan siklus satu yaitu pembelajaran menulis surat pribadi. Siklus dua dilaksanakan dua kali tatap muka. Proses pembelajaran berlangsung seperti siklus kesatu dengan perbedaan pada teknik pembelajaran dan skenario pembelajaran. Pada siklus dua guru menerangkan hasil refleksi pada siklus satu. Pelakasanaan pembelajaran pada menulis surat pribadi dengan menerapkan teknik pelatihan secara kelompok masih banyak kekurangan. Pelaksanaan pembelajaran sudah baik meskipun masih ada siswa yang tidak aktif. Pada siklus dua agar semua siswa terlibat secara aktif dalam pembelajaran menulis surat pribadi dan menghasilkan surat yang baik, maka guru menerapkan teknik pelatihan secara individual. Aktivitas berikutnya setiap siswa mempresentasikan hasilnya di depan kelas secara bergiliran. Siswa yang lain saling menanggapi, menyanggah, bertanya, dan mengkritik. Pada akhir pembelajaran siklsa dua siswa mengerjakan tugas evaluasi dengan mengerjakan LKS yang telah disusun oleh guru peneliti yaitu membuat surat pribadi. Hasil ketuntasan belajar pada pembelajaran siklus duadapat dilihat pada grafik 2 di bawah ini:

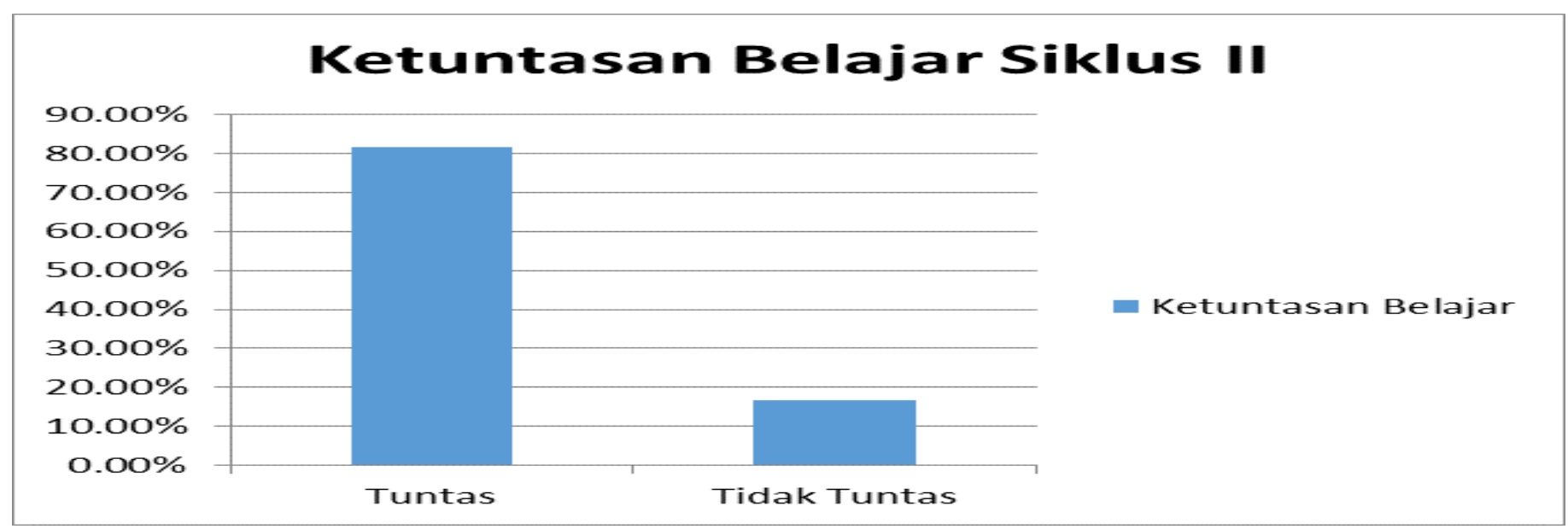

Grafik 2.

Ketuntasan Belajar Siklus II

Pada pembelajaran siklus dua, siswa yang sudah tuntas belajar dengan KKM 70,00 sebanyak 25 orang atau $81,66 \%$, sedangkan siswa yang belum tuntas belajar masih menyisakan 5 orang siswa atau 
16,66\%. Belum tuntasnya 5 orang siswa disebabkan rendahnya daya serap dan kurang serius dalam pembelajaran. Namun demikian kalau dihitung secara klasikal pembelajaran menulis surat pribadi telah memenuhi kualifikasi ketuntasan kelas sudah di atas $80 \%$ siswa tuntas belajar. Dengan demikian sesuai dengan rancangan, penelitian tindakan kelas ini sudah dianggap selesai. Pada pembelajaran siklus dua nilai rata-rata kelas naik dari 66,00 menjadi 77,83. Pelaksanaan penilaian digunakan untuk melihat data nilai. Data nilai dapat dilihat kemampuan menulis surat pribadi siswa kelas VII C SMP Negeri 9 Kota Jambi Tahun Pelajaran 2014/2015 siklus II.

\section{Tabel 3}

Kemampuan Menulis Surat Pribadi Siswa Kelas VII.3 SMP Negeri 9 Kota Jambi Tahun Pelajaran 2015/2013 Siklus II.

\begin{tabular}{clccl}
\hline Rentang Skor & \multicolumn{1}{c}{ Tingkat } & Frekuensi & Persentase & Tingkat \\
& Kemampuan & & $16,66 \%$ & Kemampuan \\
\hline $85-100$ & Baik Sekali & 5 & $50 \%$ & Baik Sekali \\
$75-85$ & Baik & 15 & $16,66 \%$ & Cukup \\
$60-75$ & Cukup & 5 & $16,66 \%$ & Kurang \\
$40-59$ & Kurang & 5 & 0 & Sangat Kurang \\
$1-39$ & Sangat Kurang & 0 & $100 \%$ & Baik \\
Jumlah & & 30 & $77,83 \%$ & \\
Rata-rata & Baik & & & \\
\hline
\end{tabular}

Berdasarkan tabel di atas, dapat diketahui kemampuan menulis surat pribadi siswa dengan kategori baik sekali berjumlah 5 orang atau 16,66\%, siswa dengan kategori baik berjumlah 15 orang atau 50\%, yang mencapai kategori cukup berjumlah 5 orang atau 16,66\%, yang mencapai kategori kurang 5 orang atau $16,66 \%$, kategori gagal tidak ada. Dengan demikian nilai rata-rata tingkat kemampuan siswa dalam menulis surat pribadi adalah 77,83. Berdasarkan nilai rata-rata tersebut dapat diketahui kemampuan menulis surat pribadi siswa tergolong kategori baik. Pada akhir kegiatan belajar siklus dua guru dan murid mengadakan refleksi setelah bersama-sama menyimpulkan hasil pembelajaran menulis surat pribadi. Hal tersebut bisa dilihat berdasarkan aktivitas siswa dalam proses pembelajaran menulis surat pribadi harian melalui teknik pelatihan pada siklus I yang disajikan dalam tabel 5 berikut ini:

Tabel 5

Hasil Pengamatan Aktivitas Siswa dalam Proses Pembelajaran Menulis Surat Pribadi Harian Melalui Teknik Pelatihan pada Siklus II

\begin{tabular}{|c|c|c|c|c|c|}
\hline No & Aktivitas siswa & P1 & $\mathbf{P 2}$ & $\begin{array}{l}\text { Rata } \\
\text {-rata }\end{array}$ & $\begin{array}{l}\text { Persentase } \\
(\%)\end{array}$ \\
\hline 1. & Siswa berinteraksi bersama teman-temanya selama pembelajaran. & 4 & 4 & 4 & 80 \\
\hline 2. & Siswa memberikan respon terhadap materi pembelajaran. & 4 & 4 & 4 & 80 \\
\hline 3. & Siswa mengajukan pertanyaan. & 4 & 5 & 4,5 & 90 \\
\hline 4. & Siswa menjawab pertanyaan. & 4 & 4 & 4 & 80 \\
\hline 5. & Siswa berperan aktif dalam pembelajaran. & 4 & 4 & 4 & 80 \\
\hline 6. & Siswa mengerjakan tugas tidak tepat waktu. & 5 & 3 & 4 & 80 \\
\hline 7. & Siswa mengungkapkan ide dalam pembelajaran. & 4 & 4 & 4 & 80 \\
\hline 8. & $\begin{array}{l}\text { Siswa mendiskusikan idenya dengan teman dan mewujudkan dalam bentuk } \\
\text { pembelajaran. }\end{array}$ & 5 & 3 & 4 & 80 \\
\hline 9. & Siswa mengganggu temannya. & 3 & 5 & 4 & 80 \\
\hline 10. & $\begin{array}{l}\text { Siswa keluar masuk kelas dalam jam pelajaran. } \\
\text { Jumlah Skor } \\
\text { Rata-rata keseluruhan } 41 \times 100 \%=80,00 \\
\qquad 50\end{array}$ & $\begin{array}{c}4 \\
41\end{array}$ & $\begin{array}{l}4 \\
41\end{array}$ & $\begin{array}{l}4 \\
41\end{array}$ & 80 \\
\hline
\end{tabular}

Kategori :

1. $>75,00$

2. $65,00-75$

$=$ Sangat Aktif

3. $55,00 \_65,00$

$=$ Aktif

4. 40,00 _ 55,00

$=$ Cukup

= Kuran Aktif 
5. $<40,00$

$=$ Tidak Aktif

Pada siklus 2 masih memilki kelemahan dan kelebihan beserta solusi yang diperoleh untuk mengatasi kelemahan tersebut, yang dapat dilihat pada tabel berikut ini:

\section{Tabel 6}

\section{Kelemahan, Kelebihan, dan Solusi dalam Siklus 2}

\begin{tabular}{|c|c|c|}
\hline Kelemahan & $\begin{array}{r}\text { Kelebihan } \\
\end{array}$ & $\begin{array}{r}\text { Solusi } \\
\end{array}$ \\
\hline $\begin{array}{l}\text { 1. Hasil pembelajaran belum memuaskan } \\
\text { (nilai siswa masih kurang ). } \\
\text { 2. Siswa dalam mengerjakan tugas belum } \\
\text { terfokus pada indikator. } \\
\text { 3. Siswa kurang mendapat perhatian } \\
\text { karena guru masih dominan dalam } \\
\text { mengarahkan siswa. }\end{array}$ & $\begin{array}{l}\text { 1. Aktfitas siswa sudah menunjukan } \\
\text { prilaku belajar. } \\
\text { 2. Sikap dan tindakan siswa sudah } \\
\text { nampak dikontrol oleh aturan. } \\
\text { 3. Sikap dan mental siswa menunjukan } \\
\text { prilaku yang alami sebagai sikap } \\
\text { yang waja dan tidak di paksakan. }\end{array}$ & $\begin{array}{l}\text { 1. Guru perlu mempertahankan } \\
\text { Kondisi siswa yang sudah } \\
\text { Menunjukan prilaku belajar. } \\
\text { 2. Meminta siswa yang sudah } \\
\text { paham untuk membantu } \\
\text { temannya. } \\
\text { 3. Pemberian reward yang dapat } \\
\text { memotifasi siswa perlu di } \\
\text { pertahankan }\end{array}$ \\
\hline
\end{tabular}

Berdasarkan data hasil menulis surat pribadi yang dicapai siswa, kemampuan siswa dalam menulis unsur-unsur menulis surat pribadi, menentukan struktur kalimat, menentukan kesesuaian isi surat, menentukan diksi surat, dan ejaan sduah mencapai kategori baik. Rata-rata nilai kelals VII C mencapai 77,83 sedangkan indikator yang ditetapkan dalam penilaian adalah 70,00. Berdasarkan data yang diperoleh dalam siklus kedua ini terjadi peningkatan, dan telah mencapai indikator kriteria ketuntasan minimal yang ditatapkan SMP Negeri 9 Kota Jambi, sehingga tidak perlu dilakukan siklus ketiga untuk memperbaiki proses pembelajaran menulis surat pribadi. Adapun perbandingan hasil tes pada siklus I dan siklus II dalam menulis surat pribadi berikut ini:

Tabel 7

Perbandingan Hasil Tes Pra Siklus I, dan II Dalam Menulis Surat Pribadi

\begin{tabular}{|l|l|l|l|}
\hline No & \multicolumn{1}{|c|}{ Hasil Tes } & \multicolumn{1}{|c|}{ Nilai Rata-Rata } & \multicolumn{1}{c|}{ Tingkat Kemampuan } \\
\hline 1 & Siklus I & 66,00 & Cukup \\
2 & Siklus II & 77,83 & Baik \\
\hline
\end{tabular}

Berdasarakan tabel 7 di atas diketahui bahwa nilai rata-rata kemampuan siswa dalam menulis surat pribadi pada hasil pra siklus ke siklus kesatu mengalami peningkatan hasil tes siklus kesatu ke siklus kedua mengalami peningkatan dari 66,00 menjadi 77,83 atau dari tingkat kemampuan cukup menjadi tingkat kemampuan baik. Dengan demikian dalam proses pengelolaan pembelajaran dengan penerapan teknik pelatihan perorangan dapat meningkatkan kemampuan siswa dalam menulis surat pribadi.Berdasarkan pengamatan yang dilakukan oleh observer terhadap aktivitas siswa dalam proses pembelajaran bahasa Indonesia dalam menulis surat pribadi pada siklus II sudah mencapai standar ketuntasan.

\section{Pembahasan}

Penggunaan teknik pelatihan di dalam proses pembelajaran menulis dapat meningkatkan kemampuan menulis surat pribadi. Teknik pelatihan yang digunakan dalam proses pembelajaran menulis surat pribadi sangat membantu siswa dalam menyelesaikan tugas yang diberikan guru, karena dengan metode pelatihan siswa termotivasi aktif, disiplin, dan bertanggung jawab dalam menyelesaikan tugas. Dari aspek kognitif sebelum tindakan ini dilakukan kemampuan siswa dalam menulis surat pribadi masih tergolong pada tingkat kemampuan kurang. Setelah dilakukan penelitian tindakan kelas hasil tes kognitif pada siklus kesatu diperoleh data bahwa 14 siswa (46,33\%) yang belum mencapai KKM, dan 16 siswa (53,66\%) yang mendapat nilai lebih besar 70,00 yang mendapat nilai lebih besar atau sama dengan 7,00. Jadi siswa yang telah mencapai KKM adalah $16(53,66 \%)$. Secara klasikal hasil tindakan pada siklus satu belum menunjukkan keberhasilan karena masih kurang dari 75\% siswa yang mencapai nilai 70,00, dengan nilai 
rata-arata kelas 66,00 dengan tingkat kemampuan cukup. Dengan demikian peneliti perlu dilajutkan ke siklus dua.

Berdasarkan tes kognitif yang dilakukan pada siklus dua diperoleh data bahwa 5 sisa $(16,66 \%)$ belum mencapai KKM, dan 25 siswa $(83,33 \%)$ telah mencapai KKM. Jadi siswa yang telah mencapai KKM adalah 25 siswa (83,33\%). Secara klasikal hasil tindakan pada siklus kedua telah menunjukkan keberhasilan, dan telah mencapai indikator yang diharapkan, yaitu 83\% siswa mencapai nilai di atas 7,00. Nilai rata-rata kelas pada siklus kedua 77,33 dengan tingkat kemampuan baik. Hal ini disebabkan oleh siswa dilatih secara perorangan selain itu guru juga lebih aktif.

Berdasarkan hasil pembelajaran dari siklus satu ke siklus dua mengalami peningkatan sebesar $11,83 \%$ . Pada siklus satu siswa tuntas berjumlah 16 siswa (53,33\%) dan siswa tidak tuntas 14 siswa (53,33\%). Pada siklus dua siswa tuntas berjumlah 25 orang $(83,33 \%)$ dan 4 siswa tidak tuntas $(16,66 \%)$. Presentase ketuntasan siswa dalam menulis surat pribadi dari siklus satu ke siklus dua mengalami peningkatan dari presentase rata-rata $66,00 \%$ menjadi $77,83 \%$. Secara individual kompetensi menulis surat pribadi talah mencapai kriteria ketuntasan minimal atau melampaui batas kelulusan. Adapun kompetensi menulis surat pribadi sejak siklus satu sampai siklus dua secara umum dapat dilihat pada tabel 8

Tabel 8

Peningkatan dari Siklus I ke Siklus II

\begin{tabular}{cc}
\hline Siklus I & Siklus II \\
\hline 66,00 & 77,83 \\
peningkatan & 11,83 \\
\hline
\end{tabular}

Peningkatan rata-rata kompetensi siswa dalam menyimpulkan isi berita melalui teknik pelatihan dapat dilihat dalam grafik berikut.

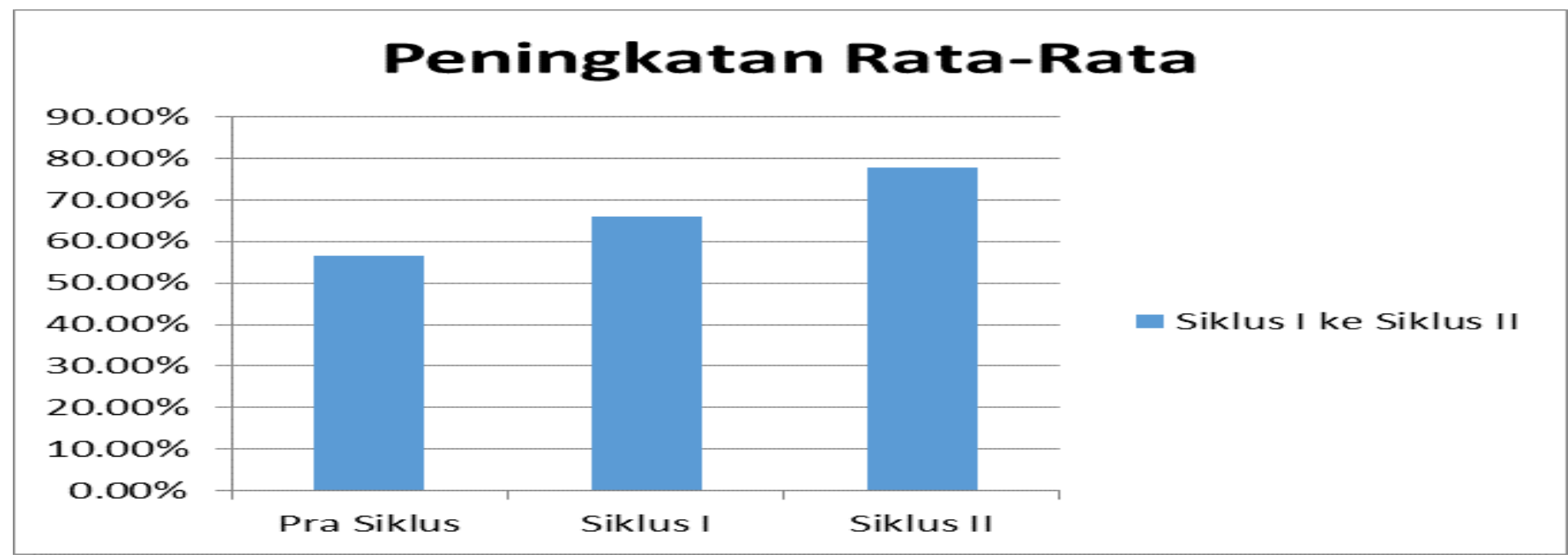

\section{Grafik 3.}

Peningkatan Rata-Rata Siklus I ke Siklus II

Pembelajaran melalui teknik pelatihan pada hakikatnya akan meningkatkan kemampuan siswa untuk mencapai kriteria ketuntasan minimal (KKM). Siswa dinyatakan tuntas belajar secara individual jika siswa memperoleh nilai 70,00. Ketuntasan belajar siswa setelah melakukan pembelajaran mulai pra siklus, siklus I, dan siklus II dapat dilihat pada tabel 9.

Tabel 9.

Ketuntasan belajar siswa setelah melakukan pembelajaran mulai pra siklus, siklus I, dan siklus II

\begin{tabular}{clll}
\hline No & \multicolumn{1}{c}{ Ketuntasan } & Siklus I & Siklus II \\
\hline 1 & Jumlah siswa tuntas & 16 & 25 \\
2 & Presentase & 56,33 & 83,33 \\
3 & Rata-rata nilai & 66,00 & 77,83 \\
\hline
\end{tabular}


Berdasarkan tabel 9 di atas menunjukkan bahwa kemampuan siswa menulis surat pribadi, pada pra siklus hanya 2 siswa $(6,66 \%)$ yang tuntas belajar dengan nilai rata-rata 56,43. Hal ini disebabkan siswa masih kesulitan dalam membuat surat pribadi, karena belum menggunakan teknik pelatihan. Realita selama ini pembelajaran menulis surat pribadi selalu disampaikan dengan ceramah, dan penugasan biasa tanpa tindak lanjut. Di samping itu, pembelajaran selalu berpusat pada guru. Pada pembelajaran siklus I 16 siswa $(53,33 \%)$ siswa tuntas belajar dengan nilai rata-rata 66,00. Hal ini berarti ada peningkatan dari pra siklus ke siklus I. peningkatan ini terjadi karena guru sudah menggunakan teknik pelatihan dalam membuat surat pribadi.

Demikian halnya dengan siklus II ketuntasan belajar menunjukkan peningkatan. Siswa yang memperoleh ketuntasan belajar yaitu 25 siswa $(83,33 \%)$ dengan nilai rata-rata 77,83. Peningkatan dari siklus I ke siklus II sangat signifikan. Hal ini karena siswa aktif dan lebih mendapatkan bimbingan guru. Berikut grafik ketuntasan menyimpulkan isi berita yang dibacakan dari pra siklus ke siklus I dan siklus II.

\section{SIMPULAN}

Berdasarkan temuan dan analisis dapat ditarik kesimpulan bahwa peningkatan dengan menggunakan teknik pelatihan dapat meningkatkan kemampuan menulis surat pribadi. Simpulan ini berdasarkan temuan bahwa :

1. Pembelajaran dengan menggunakan teknik pelatihan akan membantu siswa dalam meningkatkan kemampuan menulis surat pribaadi pada siswa kelas VII C SMP Negeri 9 Kota Jambi.

2. Penelitian hasil kerja siswa yang dipantau dan dilatih secara terus menerus akan membantu siswa untuk meningkatkan kemampuan menulis surat pribadi.

3. Hasil penelitian menunjukkan bahwa kemampuan awal siswa dalam menulis surat pribadi kategori kurang. Setelah dilakukan tindakan pembelajaran dengan menggunakan teknik pelatihan diperoleh ratarata nilai kemampuan menulis surat pribadi pada siklus pertama sebesar 66,00 dengan kategori cukup. Sedangkan kemampuan menulis surat pribadi pada siklus dua diperoleh nilai rata-rata 77,83 dengan kategori baik mengalami peningkatan 11,33 atau 17,20\%. Setiap tindakan terjadi peningkatan di antaranya ketuntasa belajar pada siklus I ketuntasan siswa sebanyak 16 atau 53,66\%, dan 25 siswa atau $83,33 \%$ pada siklus II.

\section{DAFTAR PUSTAKA}

Darmayanti, Nani. 2008. Komunikatif dalam Berbahasa Indonesia. Jakarta : PT Indah Jaya Adipratama. Djamarah, Syaiful Bahri. 1995. Strategi Belajar Mengajar. Jakarta : Rineka Cipta. Departemen Pendidikan dan Kebudayaan. 1991. Kamus Besar Bahasa Indonesia. Jakarta : Balai Pustaka.

Dwi Lestari, Endang dkk. 2005. Pelajaran Bahasa dan Sastra Indonesia. Klaten : Intan Pariwara.

Irman, Mokhamad dkk. 2007. Bahasa Indonesia. Jakarta : Intan Sejati. M.N Fajar. 2009. Terampil Menulis Surat. Bandung : Puri Deleo. Nurviati, Imas Eva. 1995. Keterampilan Menulis. Jakarta : Grup Gafiti.

Poerwadarminta, W.J.S. 1984. Kamus Umum Bahasa Indonesia. Jakarta : Balai Pustaka.

Rahayu, Rani Budi. 1994. Bahasa dan Sastra Indonesia. Bandung : Armico.

Roestiyah. N. K. 2008. Strategi Belajar Mengajar. Jakarta : Rideka Cipta.

Slamet dan Syahban Sutomo. 1996. Surat Menyurat. Surakarta : Seti Aji.

Suzan, Ronny dan Rudi Purwanto. Bahasa Indonesia. Bogor : CV Bina Pustaka.

Tarigan, Henry Guntur. 1984. Menulis Surat Keterampilan Berbahasa. Bandung : Angkasa. 